\title{
RELATIONSHIP OF SUCCESS IN UNIVERSITY STUDY AND ADMISSION EXAM RESULTS
}

\section{Julie Poláčková, Libuše Svatošová}

\section{Abstract}

The admission examinations represent a first important moment in academic education. If the admission proceedings really are expected to satisfy the intention to select those most capable and fittest candidates for study, proper attention has to be paid to them. Besides checking and confirming satisfactory levels of the results of secondary school studies they also should predict with sufficient reliability the academic success of study in the given branch. The paper brings research results concerning the given problems at the Faculty of Economics and Management CULS in Prague.

The paper is focused on the examining relationship between study results and admission exam results in Bachelor study at Faculty of Economics and Management CULS over 2008-2011. The current analysis was made for 1251 students who passed the admission exams in 2008 and passed at least 30 exams during Bachelor degree. The relationship between study results and admission exam results was examined by Spearman rank correlation coefficient. The research also concentrates on the question how much the success of study can be predicted based on results of admission proceedings. As a data sample was chosen the Informatics branch of Bachelor full-time study. The relationship between admission exam results and average progress was examined by regression analysis.
Czech University of Life Sciences Prague

polackova@pef.czu.cz

ARTICLE INFO

Article type

Full research paper

doi: 10.7160/eriesj.2013.060406

Article history

Received: July 31, 2013

Received in revised form: September 21, 2013

Accepted: October 3, 2013

Available on-line: December 31, 2013

\section{Key Words}

Admission Proceedings, Academic Success, Bachelor Degree Study, Regression and Correlation Analysis, SAS 


\section{Introduction}

Universities represent the highest level of the education system. They are the top centre of erudition, independent knowledge and creative activity. They supply and develop university education and contribute this way to the development and exploitation of scientific knowledge. They have the key role in scientific, cultural, social and economic development of the society. Fundamental mission of universities is to prepare high quality specialists for practice. Fulfilment of this mission can express and measure the level of quality of the university.

Many factors affect materialization of this demanding and highly important task. A significant factor in this sense is admission and selection of candidates for study. The problems of candidates' selection are an object of intensive interest both on side of the university and on side of the candidates. As regards current situation when the numbers of candidates exceed the university's capacity it is highly important to make the best decision on the ways of selection. The student selection principles differ from country to country and as regards different stages of the procedure, as it concerns the situation in tertiary domain of education's development (elite universities systems, higher specialist education, etc.) and taking into question the assessment of secondary school study (State school-leaving exams). The criterion of hereditary privileges in the elite systems gave way, during the last century, to the merit system where success is measured on basis of study results at secondary school level or of admission exam results.

The admission proceedings system as introduced at Czech universities, has then to answer questions, what criteria of selection are to be chosen, what qualities and capabilities are to be required from the candidates, what is the best way to assess and quantify the criteria chosen in order to select those candidates on basis of these, who not only have the best predispositions for study in general, but have the same for study at the faculty or university they have chosen. This is the assumption for education of the best possible specialists for practice and the assumption for strengthening and maintenance of the university prestige, at the same time.

The university acceptance rate on Czech universities amounts to more than $70 \%$ in 2011 (Konečný et al, 2012). Conditions of the admission proceedings differ at separate universities and faculties. In some cases there are no admission exams, at some universities the exams in special subjects are replaced by a test paper in general predispositions for study, some lay the basis for admission on National comparative examinations. However, a prevailing majority of traditional universities are keeping to the classical admission proceedings with own test papers in special subjects. The admission exam at the Faculty of Economics and Management CULS, Prague has two parts: test from mathematics (maximal 50 points) and test from foreign (English or German or French) language (maximal 50 points). The tests had form of multiple choices. The exams during the study at FEM are as usual at Czech universities ranked on 4 points scale, where 1 means excellent and 4 means fail.

The degree of satisfaction of the principal aim of admission exams, i.e. whether students having the best predispositions for study have been selected, can be assessed mostly when analysing success of study at the university or faculty given, where also the outcomes of admission proceedings are considered one of the factors. According to the fact that a longer lapse of time is needed here (successful termination of study at Bachelor or Master degree level requires three or two years), and a multidimensional data system has to be processed, analyses of this type usually are not so frequent. 
Most of the research papers published deal with the admission proceedings format, admission exam description and candidates' knowledge at the exam assessment. An investigation into not only the knowledge levels but the predispositions for study, too, is currently being performed on a long-term basis by the academic staff members of the 3rd Faculty of Medicine, Charles University (Höschl and Kožený, 1997, Kožený and Tišanská, 1995, Kožený and Höschl, 1996, Kožený and Tišanská, 2001). The candidates' knowledge is tested here by means of test papers in special subjects, their capabilities then assessed by means of selected personality tests and an oral interview. The results are subject to a very detailed statistical analysis. Besides this, the research team has paid attention to the relationship between separate parts of admission exam and the degree of academic success in study at the Faculty of Medicine (Kožený and Klaschka, 1995), where the effect of admission exam results upon the general level of study success has been definitely confirmed. Zvára and Anděl (2001) performed an assessment of study success at the Faculty of Mathematics and Physics, Charles University, during the 1993-1997 years with attention to format and results of the admission exam. Also here, the effect of admission proceedings has been proved.

Kubanová and Linda (2012a, 2012b) deal with the problem of relationship between the results of admission procedure and subsequent studies at the University of Pardubice. They focus mainly on the correlation between results of learning potential test and results of the following studies.

A study by Konečný et al (2012) based on the Sonda Maturant 1998 survey (focused on general study aptitude of final year secondary school students) showed that an admission exam model based on general study aptitude tests may improve the access of talented individuals with lower socioeconomic status to university education. Many students, especially those from secondary technical schools, could feel there was no chance of success for them in the admission procedure. The success rate of gymnasium students was significantly higher, not only due to their abilities but also because their schooling had prepared them better for the admission procedure. Due to this, many potentially successful students unfortunately never even started to aspire to university education.

Many authors also deal with the issue of relationship between success of study and variety of teaching techniques. It is mostly about monitoring of study results in distance education (see Jarkovská et al, 2011, Kunstová, 2012) and implementation of new approaches in teaching (see Houška and Beránková, 2011).

The Department of Statistics, Faculty of Economics and Management CULS, Prague, has dealt with the results of admission proceedings analyses since 1978. At the first stages the research was concentrated on admission exams only and the format of these, later on, attention started to be paid to academic study success and its relationship to admission exam results, too (Svatošová, 2000). The paper brings a comparison of the basic results of research into the relationship between academic success and admission exam results done in 1999 for 125 graduates of Economics and Management branch fulltime study and the analysis done on the population of Bachelor degree all the branches and forms of study at the Faculty of Economics and Management.

The paper is an extension of the article presented on the $10^{\text {th }}$ International Conference on Efficiency and Responsibility in Education (Poláčková and Svatošová, 2013). The paper focuses on the examining relationship between study results (annual averages) and admission exam results in Bachelor study at Faculty of Economics and Management CULS over 2008-2011. 
The current analysis was made for 1,251 students who passed the admission exams in 2008 and passed at least 30 exams during Bachelor degree (final exam was not needed). Methods of correlation analysis have been used for the measuring strength of relationship between admission exam results (points) and average progress.

The research also concentrates on the question how much the success of study at the Faculty of Economics and Management CULS, Prague, can be predicted based on results of admission proceedings. As a data sample was chosen only an Informatics branch of Bachelor full-time study. The relationship between admission exam results (points) and average study results in Informatics branch was examined by regression analysis.

The aim of this paper is using the correlation analysis for the measuring strength of relationship between admission exam results (points) and average progress and using the regression model to estimate a type of relation between chosen variables.

All statistical analyses were realized by SAS Enterprise Guide version 5.1 .

\section{Materials and Methods}

The presented paper deals with a modelling of relations between study results and admission exam results. The relationship was assessed at the first stage using Spearman rank correlation coefficient; at the next stage of research the simple regression model was used.

Methods of regression and correlation analysis have been used for the statistical analyses. The relationship between study results and admission exam results was examined by means of Spearman rank correlation coefficient, the rate of effect of admission proceedings upon success of study was then analysed using a simple regression model.

First the distribution of data was examined. The normal distribution is characterized by a bell shape and two parameters: the mean and the standard deviation. The Shapiro-Wilk test verified that the distribution of all input variables is not significantly different to the normal distribution (more in SAS Institute, 2013).

\section{Spearman rank correlation coefficient}

Spearman rank-order correlation is a nonparametric measure of association based on the ranks of the data values. The procedures for finding the Spearman correlation contain converting the $x$ a $y$ data into ranks separately and computing the sum of the squares of the differences between the $x$-ranks and corresponding $y$-ranks. Spearman correlation coefficient $\theta$ is denoted by

$$
\theta=\frac{\sum_{i}\left(\left(R_{i}-\bar{R}\right)\left(S_{i}-\bar{S}\right)\right)}{\sqrt{\sum_{i}\left(R_{i}-\bar{R}\right)^{2} \sum\left(S_{i}-\bar{S}\right)^{2}}},
$$

where $R_{i}$ is the rank of $x_{i^{\prime}} S_{i}$ is the rank of $y_{i^{\prime}} R$ is the mean of the $R_{i}$ values, and $\bar{S}$ is the mean of the $S_{i}$ values (Deep, 2006, SAS Institute, 2013).

The range of the Spearman coefficient is from -1 (perfectly monotonic) to 0 (no consistent change) to 1 (perfectly monotonic), with the sign indication the direction of the trend. The Spearman correlation is equal to the Pearson correlation of ranks when there are no ties (Deep, 2006). 


\section{Regression analysis}

The main objective of linear regression is to assess the significance of the predictor variables in explaining the variability or behaviour of the response variable and predict the values of the response variable given the values of the predictor variables.

The simple linear regression models the dependent variable $Y$ as a linear function of independent variable as follows:

$$
Y_{i}=\beta_{0}+\beta_{1} X_{i}+\varepsilon_{i^{\prime}}
$$

for the observations $i=1,2, \ldots n$; where $\beta_{0}$ is an intercept parameter, which corresponds to the value of the response variable when the predictor is 0 ; and $\beta_{1}$ is a slope parameter, which corresponds to the magnitude of change in the response variable given a one-unit change in the predictor variable. $\varepsilon$ is an error term representing deviations of $Y$ about $\beta_{0}+\beta_{1} X$.

Estimation of the unknown population parameters $\beta_{0^{\prime}} \beta_{1}$ is obtained by the method of least squares. This method provides the estimates by determining the line that minimizes the sum of the squared vertical distances between the observations and the fitted line. If the assumptions of simple linear regression are valid, the least squares estimates are unbiased estimates of the population parameters and have minimum variance (Hebák et al 2005, Huber et al 2006, Mason et al 2003, SAS Institute, 2013).

To determine whether the predictor variable explains a significant amount of variability in the response variable, the linear regression model is compared to the baseline model. The fitted regression line in a baseline model is a horizontal line across all values of the predictor variable. The slope of the regression line is zero and the intercept is the sample mean of the response variable. In a baseline model, there is no association between the response variable and the predictor variable.
The null hypothesis of the model:

$$
\beta_{1}=0 \text {, }
$$

It means that regression model does not fit the data better than the baseline model (Hebák et al 2005, Huber et al 2006).

The coefficient of determination is usually referred to as the $R^{2}$ value. The value is the proportion of variability observed in the data explained by the regression line. The coefficient of determination is written:

$$
R^{2}=1-\frac{S S_{E}}{T S_{k}}
$$

where $S S_{E}$ is the sum of squares of residuals and $T S_{E}$ is the total sum of squares (Huber et al, 2006, Mason et al, 2003).

\section{Regression Diagnostics}

Regression diagnostics verify that the data have met the regression assumptions; otherwise the results may be misleading. Assumptions for linear regression are following.

- The random error term, $\varepsilon$, is assumed to have a normal distribution with a mean of zero, $E|\varepsilon|=0$.

- The variance of the error for the $i^{\text {th }}$ observation is $\sigma^{2} / w_{i^{\prime}}$ where $w_{i}$ is a known weight factor. Usually, $w_{i}=1$ for all $i$ and thus $\sigma^{2}$ is the common, constant variance.

- The errors should be independent; errors associated with one observation are not correlated with errors of any other observation.

A common way to check the homogeneity of variance (homoscedasticity) of the residuals is to plot the residuals versus predicted values. Another way is to use the White test, which tests the null hypothesis that the variance of the 
residuals is homogenous. The Shapiro-Wilk test verified that the distribution of residuals is not significantly different to the normal distribution (Huber et al, 2006, SAS Institute, 2013).

A single observation that is substantially different from all other observations can make a large difference in the results of the regression analysis. There are three ways that an observation can be unusual: outliers, leverage, or influence. In linear regression, an outlier is an observation with large residual. An outlier may indicate a sample peculiarity, data entry error or other problem. An observation with an extreme value on a predictor variable is called a point with high leverage. Leverage is a measure of how far an independent variable deviates from its mean. These leverage points can have an effect on the estimate of regression coefficients. An observation is said to be influential if removing the observation substantially changes the estimate of coefficients. Influence can be thought of as the product of leverage and outlierness (see Chen et al, 2003, Hebák et al, 2005). Measure of influence, Cook's D, measures the change to the estimates that results from deleting an observation. For more information, see Cook (1979).

\section{Results}

Table 1 shows the descriptive statistics for average study results variable used in this study. For the 2008 academic year, there were 1,251 students passed at least 30 exams during Bachelor degree. The best results in average study progress (smallest value of score) reached small branches in full-time study form: HKS (mean 1.93) and AEM (2.14). On the other hand PAE and INFO branches, reached the highest average value of score, which means worst study results.

\begin{tabular}{|c|c|c|c|c|c|c|c|}
\hline Branch & $\begin{array}{c}\text { Study } \\
\text { form }\end{array}$ & $\mathrm{N}$ & Mean & $\begin{array}{c}\text { Standard } \\
\text { Deviation }\end{array}$ & Minimum & Maximum & $\begin{array}{c}\text { Coeff of } \\
\text { Variation } \\
(\%)\end{array}$ \\
\hline AEM & full-time & 20 & 2.14 & 0.28 & 1.52 & 2.73 & 13.29 \\
\hline HKS & full-time & 69 & 1.93 & 0.37 & 1.25 & 3.00 & 19.40 \\
\hline INFO & full-time & 87 & 2.44 & 0.36 & 1.61 & 3.14 & 14.92 \\
\hline INFO & combi & 38 & 2.42 & 0.41 & 1.27 & 3.12 & 16.86 \\
\hline PAA & full-time & 297 & 2.42 & 0.37 & 1.23 & 3.50 & 15.51 \\
\hline PAE & full-time & 395 & 2.48 & 0.37 & 1.35 & 3.42 & 14.95 \\
\hline PAE & combi & 131 & 2.54 & 0.37 & 1.42 & 3.54 & 14.37 \\
\hline SYI & full-time & 26 & 2.33 & 0.44 & 1.29 & 3.4 & 18.77 \\
\hline VSRR & full-time & 188 & 2.20 & 0.37 & 1.16 & 3.21 & 16.71 \\
\hline
\end{tabular}

Table 1: Descriptive analysis of the average study results

$\begin{array}{lll}\text { Exp.: } & \text { PAE } & \text { Business and Economics } \\ & \text { PAA } & \text { Entrepreneurship and Administration } \\ \text { INFO } & \text { Informatics } \\ \text { SYI } & \text { Systems Engineering } \\ \text { VSRR } & \text { Public Administration and Regional Development } \\ \text { HKS } & \text { Economic and Cultural Studies } \\ \text { AEM } & \text { Agricultural Economics and Management }\end{array}$

Also the distribution of data was examined. The Shapiro-Wilk test verified that the distribution of all input variables, except greatest branches PAA and PAE, is not significantly different to the normal distribution.

Figure 1 shows box plots of average study results by branches. The bottom and top of the box represent the first and third quartiles, and the band inside the box represents the second 
quartile (the median). The rhombus represents the mean of the average study results. Whiskers symbolize the lowest value still within 1.5 interquartile range (IQR) of the lower quartile, and the highest value still within 1.5 interquartile range of the upper quartile. Outliers are plotted as individual points.

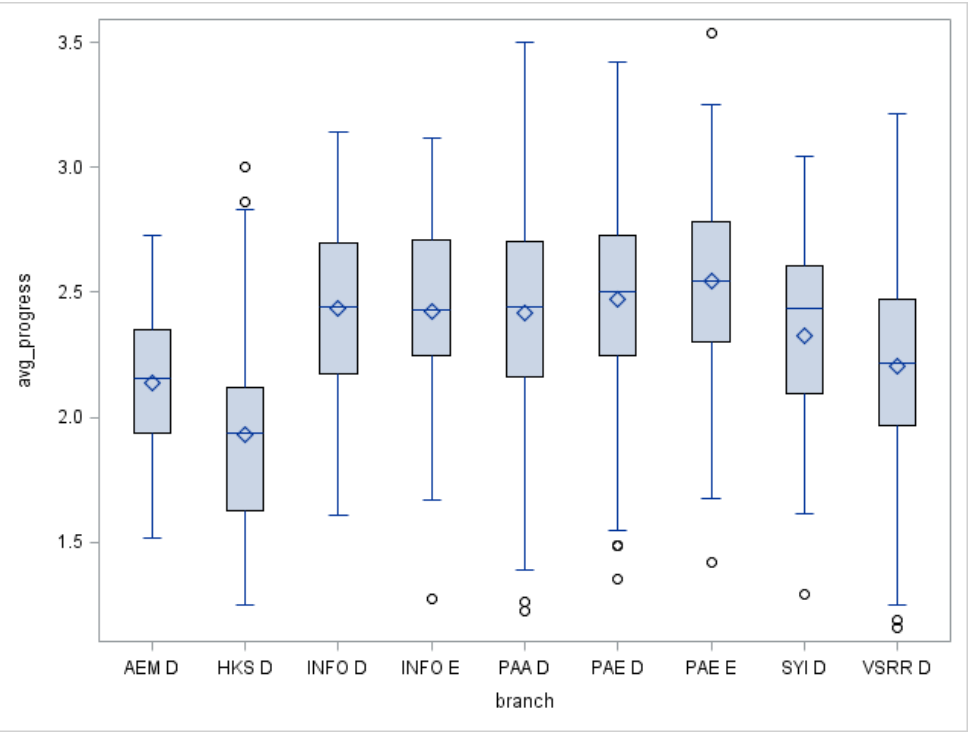

Figure 1: Comparison of average study results by branches

The research was concentrated on questions concerning the relationship between admission proceedings results and academic success in Bachelor study at FEM, especially on their impact and the impact of their parts - maths test paper and foreign language test paper - on study results at FEM.

At the first research stage, the relationship was assessed between admission proceedings results and study results at FEM using correlation analysis. Considering nature of the data, Spearman rank correlation coefficient was employed to determine strength of the relationship

Numbers of points gained for maths test paper and language test paper were engaged as input data (independent variable values) as well as the total number of points. Study averages for the separate years of study as well as total average for the whole of Bachelor study were used for the output data. Analysis was performed first for the whole of the population and then also for groups by the study form. Results are given in Table 2 and Table 3.

\begin{tabular}{|l|c|c|c|}
\hline \multirow{2}{*}{ Study form } & \multicolumn{3}{|c|}{ Spearman correlation coefficient } \\
\cline { 2 - 4 } & Total & Mathematics & $\begin{array}{c}\text { Foreign } \\
\text { language }\end{array}$ \\
\hline Graduates total & -0.386 & -0.248 & $\mathbf{- 0 . 3 3 2}$ \\
\hline Graduates full-time study & -0.380 & -0.230 & $\mathbf{- 0 . 3 4 4}$ \\
\hline Graduates combi study & -0.427 & $\mathbf{- 0 . 3 5 8}$ & -0.277 \\
\hline
\end{tabular}

Table 2: Spearman correlation coefficient values measuring strength of relationship between admission exam results (points) and average progress in Bachelor study at Faculty of Economics and Management CULS over 2008-2011

As results on Table 2 show it, the relationship between total study progress at FEM CULS and the admission exam results exists. All the correlations presented in Table 2 are statistically significant. Negative value of correlation coefficients means that the study results (average grade) tend to decrease in value as the admission exam results (points) increase in value. A higher level is seen in the group of combined study form graduates. If the effect of separate admission exam subjects is compared then 
a stronger impact belongs to language test paper result. Math test paper result is observed more distinctly in the combined study graduates group, while the language test paper result shows a stronger impact on study at FEM in the full-time form graduates group. If the relationship between admission proceedings results and study progress in separate years of study is examined then the strongest correlation has been obtained for the first year of study.

\begin{tabular}{|l|c|c|c|c|}
\hline \multirow{2}{*}{$\begin{array}{l}\text { Branch } \\
\text { of study }\end{array}$} & \multirow{2}{*}{$\begin{array}{c}\text { Study } \\
\text { form }\end{array}$} & \multicolumn{3}{|c|}{ Spearman correlation coefficient } \\
\cline { 3 - 5 } & & Total & Mathematics & $\begin{array}{c}\text { Foreign } \\
\text { language }\end{array}$ \\
\hline PAE & full-time & -0.314 & $\mathbf{- 0 . 2 5 8}$ & -0.237 \\
\hline PAE & combi & -0.404 & -0.289 & $\mathbf{- 0 . 3 0 1}$ \\
\hline PAA & full-time & -0.327 & -0.187 & $\mathbf{- 0 . 3 0 7}$ \\
\hline INFO & full-time & -0.595 & $\mathbf{- 0 . 5 4 7}$ & -0.471 \\
\hline INFO & combi & -0.537 & $\mathbf{- 0 . 5 3 7}$ & -0.221 \\
\hline SYI & full-time & -0.519 & $\mathbf{- 0 . 4 5 8}$ & -0.389 \\
\hline VSRR & full-time & -0.300 & -0.136 & $\mathbf{- 0 . 2 5 9}$ \\
\hline HKS & full-time & -0.386 & -0.159 & $\mathbf{- 0 . 3 8 4}$ \\
\hline AEM & full-time & -0.346 & -0.208 & $\mathbf{- 0 . 4 2 2}$ \\
\hline
\end{tabular}

Table 3: Spearman correlation coefficient values measuring strength of relationship between admission exam results (points) and average progress in separate branches of Bachelor study at Faculty of Economics and Management CULS over 2008-2011
Considering the Bachelor study candidates' possible choice from seven branches of study at FEM CULS during the given period, every branch having its own special profile and its own special requirements as concerns the candidate's previous knowledge, too. The next stage of research was concentrated on the question, which of the admission exam subjects applies a stronger influence on study success of the given study branch.

Table 3 shows that a stronger correlation between the results of Bachelor study and the admission exam results has been registered for the study branches Informatics and Systems Engineering - these are rather more technology oriented. Here also the correlation between the Bachelor study results and the maths admission test paper results is at a higher level. On the other hand, the HKS, VSRR and PAA branches, that include many study subjects aimed at humanitarian activities, register a stronger relationship between general study results and the language admission test paper results. The same holds for the AEM study branch where, naturally, a good knowledge of the foreign language is a condition sine qua non for successful study.

The paper also concentrates on the question how much the success of study at the Faculty of Economics and Management CULS, Prague, can be predicted based on results of admission proceedings. As a data sample was chosen an Informatics branch of Bachelor full-time study over 2008-2011. The relationship between average study results (dependent variable) and admission exam results (independent variable) in Informatics branch was examined by regression analysis.

The objective of regression analysis is to examine and describe the relationship between continuous variables. The null hypothesis is: the linear regression model does not fit the data better than the baseline model. 
As one observation was found to be highly influential by Cook's D statistic, which means that removing this observation substantially changes the estimate of coefficients, it was excluded from the analysis. Therefore the refitted model was created. The coefficient of determination increases from $34.3 \%$ to $39.2 \%$

Table 4 shows that the p-value ( $\operatorname{Pr}>\mathrm{F}$ column) of the refitted model is less than 0.05 , therefore there is enough evidence to reject the null hypothesis $\left(\beta_{1}=0\right)$ at the 0.05 significance level. The simple linear regression model fits the data better than the baseline model. The admission exam results explain a significant amount of average progress in Informatics branch.

\begin{tabular}{|c|c|c|c|c|c|}
\hline \multicolumn{7}{|c|}{ Analysis of Variance } \\
\hline Source & $\begin{array}{c}\text { Degrees } \\
\text { of Freedom }\end{array}$ & $\begin{array}{c}\text { Sum } \\
\text { of Squares }\end{array}$ & $\begin{array}{c}\text { Mean } \\
\text { Square }\end{array}$ & F Value & Pr $>$ F \\
\hline Model & 1 & 4.25982 & 4.25982 & 54.11 & $<.0001$ \\
\hline Error & 84 & 6.61271 & 0.07872 & & \\
\hline $\begin{array}{c}\text { Corrected } \\
\text { Total }\end{array}$ & 85 & 10.87253 & & & \\
\hline
\end{tabular}

\begin{tabular}{|c|c|c|c|c|c|}
\hline \multicolumn{7}{|c|}{ Parameter Estimates } \\
\hline Variable & $\begin{array}{c}\text { Degrees of } \\
\text { Freedom }\end{array}$ & $\begin{array}{c}\text { Parameter } \\
\text { Estimate }\end{array}$ & $\begin{array}{c}\text { Standard } \\
\text { Error }\end{array}$ & $\mathrm{t}$ Value & $\operatorname{Pr}>|\mathrm{t}|$ \\
\hline Intercept & 1 & 3.32361 & 0.12533 & 26.52 & $<.0001$ \\
\hline $\begin{array}{c}\text { Admission } \\
\text { exam results }\end{array}$ & 1 & -0.01527 & 0.00208 & -7.36 & $<.0001$ \\
\hline
\end{tabular}

Table 4: Simple linear regression results

The coefficient of determination of this model is 0.3918 , which means that the regression line explains $39.18 \%$ of the total variation in the response values. The relationship between the response variable and the predictor variable can be characterized by the regression equation, as follows:

Average study results' $=3.324-0.015 \times$ Admission exam results.

The estimated coefficient for predictor variable corresponds to the magnitude of change in the response variable given a one-unit change in the predictor variable. The negative value of the coefficient $(-0.015)$ means that average study result tends to decrease in value as the admission exam result increases in value. It means that student with high admission exam results reached better results (lower score) in future study than student with few points.

The fitted regression line is shown in Figure 2.

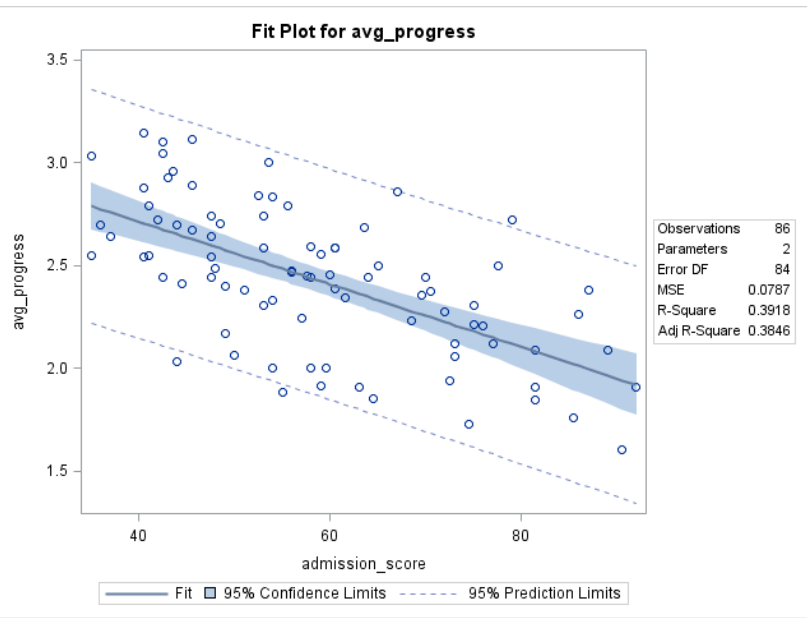

Figure 2: Fitted regression line of average progress in Informatics branch at Faculty of Economics and Management CULS over 20082011 
Next the regression diagnostics was created; the diagnostics plots are shown on Figure 3. Regression diagnostics verify that the data have met the regression assumptions. Four outlier observations and six observations with high leverage were found in the data. Any of these students were not found to be highly influential.

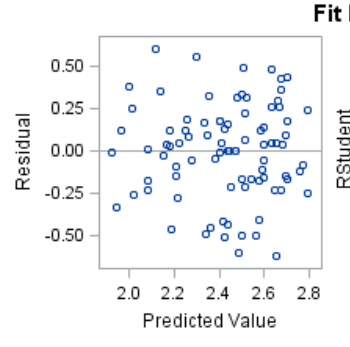

\section{Fit Diagnostics for avg_progress}
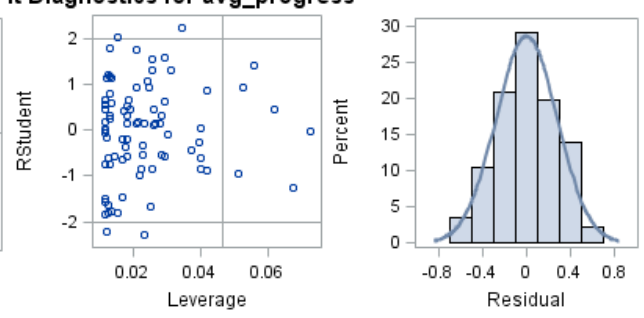

Figure 3: Diagnostics plots of fitted regression model

The other assumptions of linear regression were also examined. The scatter plot of residual values (Figure 3) shows that residuals appear to be randomly scattered about the reference line at zero. There are no apparent trends or patterns in the residuals. Null hypothesis that the distribution of residuals is not significantly different to the normal distribution was verified by the Shapiro-Wilk test. As the p-value 0.58 is higher than the 0.05 significance level, the null hypothesis was not rejected. The homogeneity of variance was checked by the White test of First and Second Moment Specification. The p-value 0.61 of White's test is higher than the 0.05 significance level, thus the null hypothesis (residuals are homoscedastic) was also not rejected. All assumptions of linear regression have been proven.

\section{Discussion}

It is widely understood that student's demographics and incoming academic ability are important predictors of a student's ability to persist students' success (Ishitani, 2006). Jones-White et al (2010) found that not only background and precollege characteristics are important, but also that admission to a student's first choice college and first-term academic progress, were significant predictors of academic success.

The academic performance of matriculants at public medical schools in Iran from entrance through internship was analysed by Farrokhi-Khajeh-Pasha et al (2012). Pearson correlation and regression analyses were used to assess the relationships between the selection criteria and academic performance. The results show that care should be taken to develop comprehensive admissions criteria to identify the best applicants. Our research using similar methodology as Farrokhi-Khajeh-Pasha et al (2012) also found out that admission examination results in relevant branches at the FEM CULS provide significant predictor of student success. Also Rubešová (2009) proved in her work that study success at the Faculty of Science, Charles University, connects definitely both to admission proceedings results and to the previous secondary school education progress.

The basic analysis at University of Economics, Prague confirmed that the output knowledge of students, with a different type of study, is comparable. The form of compensation of direct teaching for distance students is probably sufficiently replaced by e-learning materials (Kunstová, 2012). The current research also shows that average study results of full-time students is not different to results of students in combi study form.

The process that influences a student's choice to persist in university education is complex. The generalizability of these 
results is limited to the entering freshman class in relevant branches at the FEM CULS. The identified relationships between study results and admission exam results may not apply to other environments. The limitation of linear regression model stems from the limited set of variables incorporated into the model. Future research will focus on more complex model of student success; it will include also socio-demographic factors, number of attempts on exams, and results of the final exam.

\section{Conclusion}

The paper was focused on examining and quantifying the relationship between study results and admission exam results. For this purpose, Spearman correlation and simple linear regression analysis were used. Comparing the correlation coefficients of maths and language admission test paper results with average study results, showed that Informatics and Systems Engineering branches had a higher correlation with maths test results, and more humanities-oriented branches (HKS, VSRR, AEM and PAA) had a higher correlation with language test results.

The question how much is the success of study in Informatics branch at the Faculty of Economics and Management CULS, Prague, related with results of admission proceedings was analysed by regression analysis. The linear relationship between the response variable (average study results) and predictor variable was defined by regression equation: Average study results' $=3.324-0.015$ Admission exam results.

The regression line explains $39.2 \%$ of the total variation in the response values. These findings proved that admission examinations can predict the academic success of study in the given branch with sufficient reliability. The analysis can suggest which freshmen are likely to be successful at academic study.
The success of study at the Bachelor degree level with Faculty of Economics and Management CULS in Prague is evidently connected to the results of admission proceedings. It can be taken proven that the admission proceedings are performed at a well qualified level and the success of study for the Bachelor degree at this Faculty can be predicted on basis of the proceedings results. The different rate of impact of separate subjects of the admission exam at the different FEM study branches could bring changes of the admission proceedings in future. The level of difficulty of exam test papers for the subjects tested could be changed down or up according to knowledge level required for the given study branch.

As it has been stated above, impact of the admission proceedings results upon the success of study for the Bachelor degree can be taken proven. It can be said, hence, that the current system of admission proceedings, where the Faculty bodies themselves establish priorities in the entrance knowledge needed for study in the study branch given, is purposeful and its replacement by other systems (State school-leaving exam results, general study predispositions test results, etc.) might not bring the effect desired, i.e., selection of candidates having predispositions for study of a concrete study branch.

\section{Acknowledgements}

The paper was elaborated in the framework of solution of the research intention MŠMT-MSM 6046070906, in the stage 6.2.1. "Modelling and forecasting of development of decisive indicators of economic and social development in the $C R$ and in the context with the EU". 


\section{References}

Cook, R. D. (1979) 'Influential Observations in Linear Regression', Journal of the American Statistical Association, vol. 74, pp. 169-174.

Deep, R. (2006) Probability and Statistics with Integrated Software Routines. London: Elsevier.

Farrokhi-Khajeh-Pasha, Y., Nedjat, S., Mohammadi, A. et al (2012) 'The validity of Iran's national university entrance examination (Konkoor) for predicting medical students' academic performance', BMC Medical Education, vol. 12, no. 60, pp. 219-235.

Hebák, P., Hustopecký, J. and Malá, I. (2005) Vícerozměrné statistické metody [2]. Prague: Informatorium.

Höschl, C. and Kožený, J. (1997) 'Predicting Academic Performance of Medical Students: the First Three Years', American Journal of Psychiatry, vol. 154, no. 6, pp. 87-92.

Houška, M. and Beránková, M. (2011) ‘The Impact of Multimedia Lectures on Students' Performance in Two Specific Subjects', Journal on Efficiency and Responsibility in Education and Science, Vol. 4, No. 4, pp. 187-186.

Huber, M., Marovich, P. and Thielbar, M. (2006) SAS Enterprise Guide: ANOVA, Regression, and Logistic Regression. Cary: SAS Institute.

Chen, X., Ender, P., Mitchell, M. and Wells, C. (2003) Regression with SAS [online]. UCLA: Academic Technology Services, Statistical Consulting Group. [cit. 20. 4. 2011] <http://www.ats. ucla.edu/stat/sas/webbooks>.

Ishitani, T. (2006) 'Studying attrition and degree completion behavior among first-generation college students in the United States', The Journal of Higher Education, vol. 77, no. 5, pp. 861-885.
Jarkovská, M., Kučera, P., Vostrá, H. and Varvažovská, P. (2011) 'Comparing Student's Results in Distance-Studies Centres Using Statistical Analyses', Proceeding of the $8^{\text {th }}$ International Conference on Efficiency and Responsibility in Education (ERIE 2011), pp. 166-177.

Jones-White, D. R., Radcliffe, P. M., Huesman. R. L. and Kellogg, J. P. (2010) 'Redefining Student Success: Applying Different Multinomial Regression Techniques for the Study of Student Graduation Across Institutions of Higher Education', Research in Higher Education, vol. 51, no. 2, pp. 151-174.

Konečný, T., Basl, J., Mysliveček, J. and Simonová, N. (2012) 'Alternative models of entrance exams and access to higher education: the case of the Czech Republic', Higher Education, vol. 63, no. 2, pp. 219-235.

Kožený, J. and Klaschka, J. (1995) 'Predikce průměrného prospěchu studentů v 1 . roce studia medicíny', Československá psychologie. vol. 39, no. 1, pp. 19-27.

Kožený, J. and Tišanská, L. (1995) ‘Osobnostní profil studentů medicíny přijatých na 3. LF UK Praha v letech 1992-1994', Československá psychologie, vol. 39, no. 4, pp. 358-364.

Kožený, J. and Höschl, C. (1996) 'Strukturální model akademického výkonu studentů medicíny v prvních čtyřech semestrech studia', Československá psychologie, vol. 40, no. 3, pp. 177-184.

Kožený, J. and Tišanská, L. (2001) 'Akademická úspěšnost na střední škole: predátor absolvování studia medicíny', Československá psychologie, vol. 45, no. 1, pp. 1-6.

Kubanová, J. and Linda, B. (2012a) 'Learning Potential Tests and Study Success', Proceding of the $9^{\text {th }}$ International Conference on Efficiency and Responsibility in Education (ERIE 2012), Czech University of Life Sciences Prague, pp. 279-286. 
Kubanová, J. and Linda, B. (2012b) 'Relation between Results of the Learning Potential Tests and Study Results', Journal on Efficiency and Responsibility in Education and Science, vol.5, no. 3. pp. 125-134.

Kunstová, R. (2012) 'Analysis of Study Results and the Use of e-learning Materials within Distance Education', Journal on Efficiency and Responsibility in Education and Science, vol. 5, no. 4., pp. 185-194.

Mason, R., Gunst, R. and Hess, J. (2003) Statistical Design and Analysis of Experiments. New Jersey: Wiley publishing.

Poláčková, J. and Svatošová, L. (2013) 'Analysis of success in university study as connected to admission exam results', Proceedings of the $10^{\text {th }}$ International Conference on Efficiency and Responsibility in Education (ERIE 2013), CULS Prague, pp. 503-509.

Rubešová, J. (2009) 'Souvisí úspěšnost studia na vysoké škole se středoškolským prospěchem?', Pedagogická orientace, vol. 13, no. 3, pp. 89-103.

SAS Institute (2013): Base SAS(R) 9.2 Procedures Guide: Statistical Procedures, Third Edition. [online]. [cit. 20. 6. 2013]. $<$ http://support.sas.com/documentation>.

Svatošová, L. (2000) 'Přijímací řízení a akademická úspěšnost na PEF ČZU v Praze', Sborník z mezinárodní konference "Agrární perspektivy IX“, Prague: FEM CULS. [online]. [cit. 20. 6. 2013]. $<$ http://www.agris.cz/zemedelstvi?id_a=102064>.

Zvára, K. and Anděl, J. (2001) 'Souvislost výsledku přijímacího řízení s úspěšností studia na MFF', Pokroky matematiky, fyziky a astronomie, 2001, vol. 46, no. 6, pp. 304-312. 